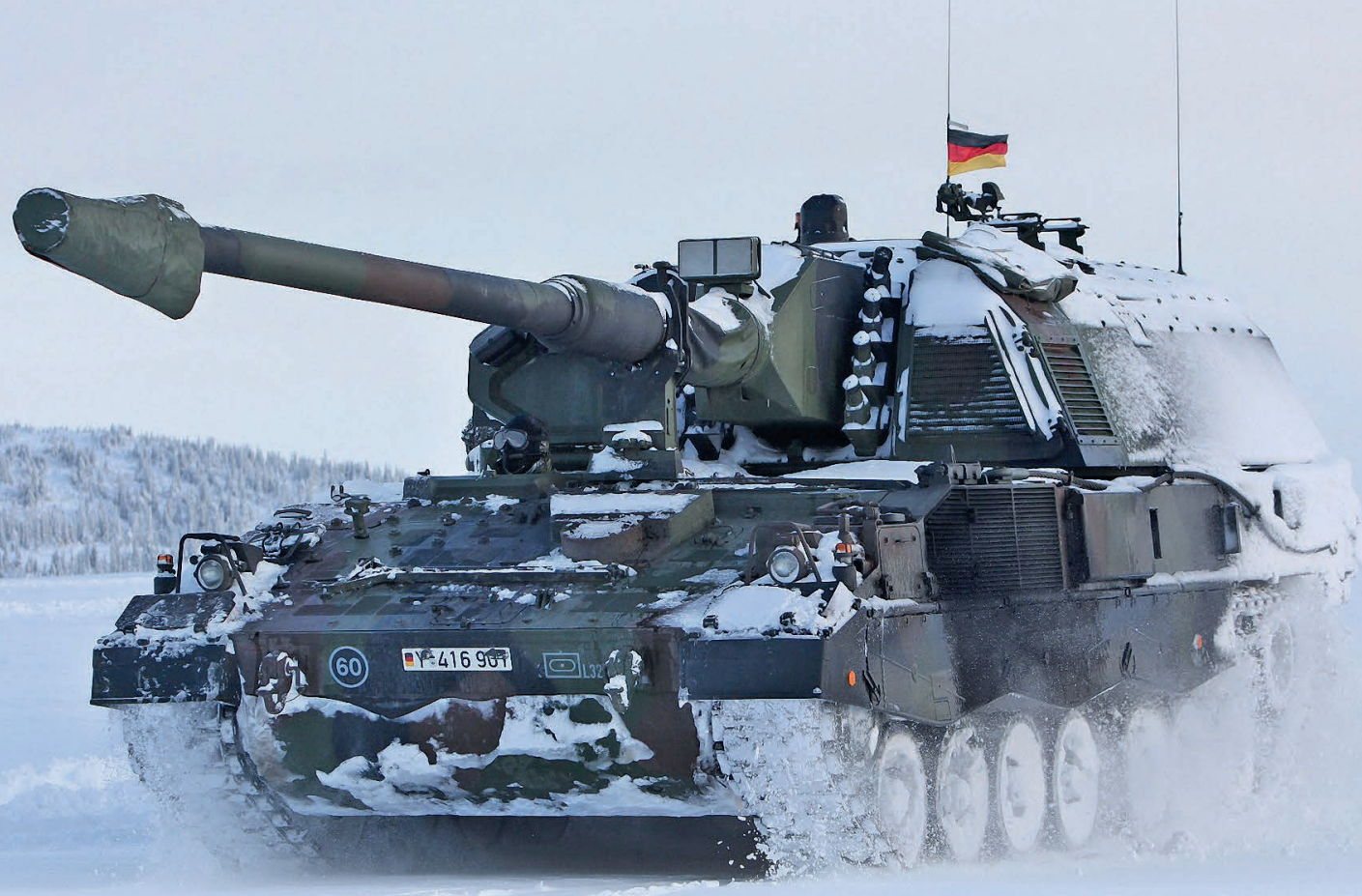

1. ábra. Az 1990-es évek elején, a Bundeswher igényei szerint fejlesztett PzH 2000-es önjáró löveg hóban, fagyban is bizonyította képeségeit (Fotó: KMW)

\title{
Sáry Zoltán*
}

\section{A PzH 2000 önjáró löveg}

2 018 végén felgyorsult a Magyar Honvédség fejlesztése. A légierőt követően a szárazföldi haderőnem is számos új fegyverrendszert állít szolgálatba, ezen belül a tűztámogatási képesség is fontos tényezőnek számít. A hederőreform keretében a tüzérség is megújul: 24 db PzH 2000 típusú önjáró löveg kerül beszerzésre.

A típus története még a hidegháború időszakára nyúlik vissza: Nagy-Britannia, Németország és Olaszország az SP70-es önjáró löveg fejlesztésén dolgozott. A programot próbálták úgy összeállítani, hogy technikai, illetve logisztikai szempontból minél több közös pont legyen más fegyverrendszerekkel, elsősorban aLeopard harckocsicsaláddal, illetve a Marder gyalogsági harcjárművel. A közös fejlesztés végül nem vezetett eredményre, mind az olaszok, mind az angolok saját, illetve amerikai típusokat rendszeresítettek. A modernizációs törekvések keretében az amerikaiak

ÖSSZEFOGLALÁS: 2018 végén került aláíásra az a szerződés, amely alapján a Magyar Honvédség Leopard 2A7+ harckocsikat, PzH 2000 típusú önjáró lövegeket és ezekhez tartozó logisztikai jármúveket, készleteket szerez be a Zrínyi 2026 honvédelmi és haderőfejlesztési program keretében. A típus már több országban is hadrendben áll. A gondos tervezésnek és az automatizált kialakitásnak köszönhetően sok szempontból kategóriáának csúcsát jelenti. A világszínvonalú eszköz beszerzése komoly minőségi előrelépést jelent, amelynek birtokában a Magyar Honvédség katonáit a XXI. századi technológiát biztosító eszközökkel szereli fel.

KULCSSZAVAK: Magyar Honvédség, Zrínyi 2026 haderőfejlesztési program, PzH 2000 önjáró löveg, szárazföldi haderőnem, tűztámogatási képesség nekiláttak az igen előremutató Crusader programnak, amelyet végül leállítottak.

A németek Panzerhaubitze 2000 (Páncélozott tarack 2000) megnevezés alatt a következő évezred elvárásainak megfelelő, nagyszabású projektet indítottak. A főbb elvárások között szerepelt, hogy legalább $60 \mathrm{db}$ lőszert lehessen málházni benne; a rakéta póthaitás nélkül is $30 \mathrm{~km}$-t meghaladó lőtávolsága; az automatizált működés, illetve abból adódó nagy tűzgyorsaság és megbízhatóság, valamint a nagyfokú mozgékonyság. Az 1838-ig visszanyúló történetű Krauss-Maffei Wegman cég egy igen impozáns harcjármüvet készített.

A hegesztett acélpáncélzat elsősorban a kézifegyverek lövedékeitől és a repeszektől, szemből pedig a 14,5 mm-es lőszerektől biztosít védelmet. $A$ harcjárműre reaktív és kiegészítő páncélzat is felszerelhető. A páncéltest hátsó ré-
ABSTRACT: The contract according to which the Hungarian Defence Forces purchases Leopard 2A7+ tanks, PzH 2000 self-propelled howitzers and related logistics vehicles and supplies within the Zrínyi 2026 Defence and Armed Forces Development Programme was signed at the end of 2018. The howitzer of this type has already been integrated into service in several countries. Due to careful design and high-level automatization, it stands at the top of its class in many respects. Procurement of this world-class equipment represents a major step forward in quality that will enable our soldiers to have unprecedented capabilities.

KEY WORDS: Hungarian Defence Forces, Zrínyi 2026 Defence and Armed Forces Development Programme, PzH 2000 self-propelled howitzer, fire support capability

ORCID: 0000-0003-0834-4046 


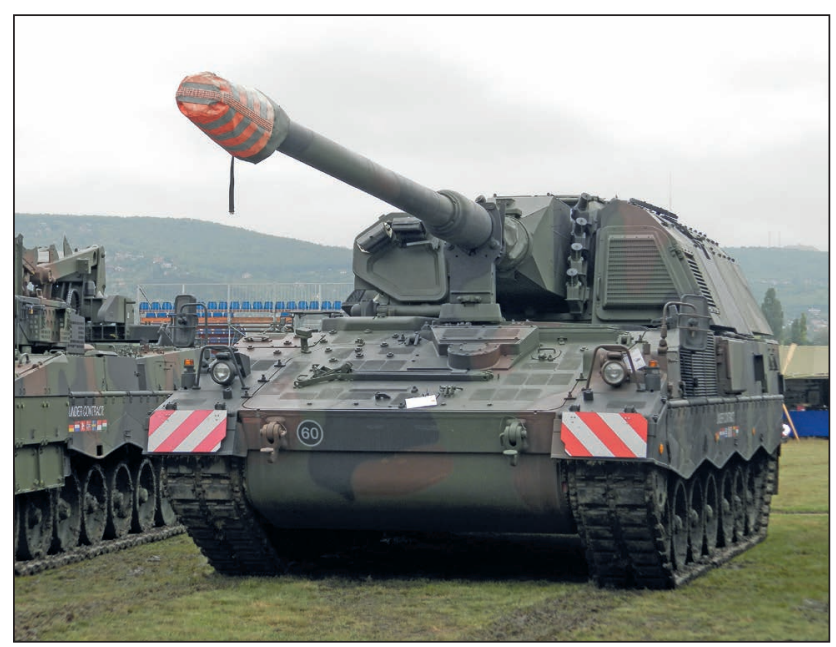

2. ábra. A Magyar Honvédség a Zrínyi 2026 program keretében 24 db PzH 2000-es önjáró löveget rendszeresít. A kép 2019-ben, a budaörsi honvédelmi nyílt napon készült (Fotó: Baranyai László)

szére egy nagy méretű búvónyílást terveztek, ami többek között vészkijáratként is funkcionál a kezelők részére. A jármű méretét próbálták úgy meghatározni, hogy a lehető legnagyobb belső térrel rendelkezzen, ugyanakkor ne korlátozza a mozgékonyságot, illetve a szállíthatóságot, ami megfelel a NATO STANAG ${ }^{1}$ elöírásainak. Az eszköz szállítható C-17-es repülőgéppel. A küzdőtér kialakításból adódóan a jármű meghajtómodulja (powerpack) előre került. Ez tartalmaz egy nyolchengeres, közvetlen befecskendezéses, feltöltött MTU M881 735 kW-os (1000 LE-s) dízelmotort, és egy négy előre- és két hátrameneti fokozatú, hidromechanikus, Renk gyártmányú, HSWL 284C típusú automata váltóművet. Az így kialakított modul egyszerűsíti az alkalmazás közbeni karbantartást és javítást. Az erőforrás esetében nemcsak a fogyasztás optimalizálására, hanem a károsanyag-kibocsátás csökkentésére is nagy hangsúlyt fektettek. Egy segédhajtóművet is beépítettek, ami autonóm módon képes az energiaellátásra, a fő motor üzemen kívüli állapotában. A PzH 2000 maximális sebessége műúton 60 , terepen $45 \mathrm{~km} / \mathrm{h}$. A kormányzás nem

3. ábra. A PzH 2000-et önjáró löveget a holland és német haderö is sikerrel alkalmazta az afganisztáni hadmúveletekben

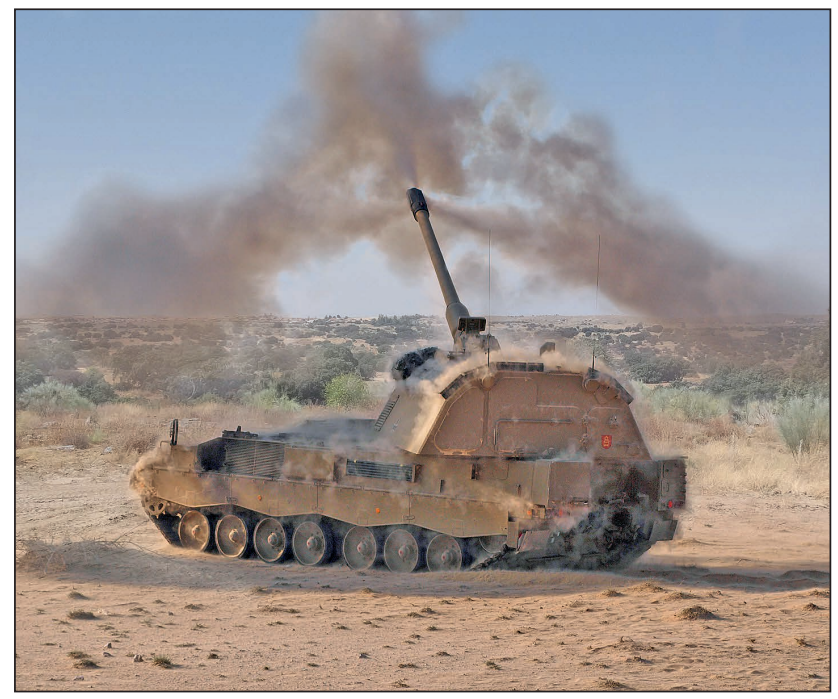

botkormány, hanem kormánykerék segítségével történik és a vezető egy színes többfunkciós képernyővel is rendelkezik. A gumibetétes lánctalp futásteljesítménye $4000 \mathrm{~km}$, ami - figyelembe véve az azonos kategóriába sorolt eszközök saját futóművön történő mozgatásának arányát - teljesen megfelelőnek mondható. A harcjármű $50 \%$-os emelkedőn képes felmenni, az oldaldőlés $25 \%$ lehet. Az árokáthidaló képessége $3 \mathrm{~m}$, lépcsőmászó képessége 1,1 m. Előkészítés nélkül 1,5 m-es gázlón is képes áthaladni.

A jármű a kor követelményeinek megfelelően navigációs rendszerrel és olyan adatcserére képes rádióval rendelkezik, amely segítségével képes a komplett lőelemeket is egy vezetési pontról irányítani. A karbantartásnál hasznos a szintén beépített fedélzeti ellenőrző berendezés (Built-In Test Equipment - BITE - System).

A Leopard családon alapuló tervezési elveknek köszönhetően a PzH 2000 mozgékonysága a harckocsikhoz hasonló, ami nemcsak harcászati előnyökkel jár, hanem a hadműveleti, illetve logisztikai tervezést is megkönnyíti. ${ }^{2}$ A lőszerrel, üzemanyaggal feltöltött harcjármű tömege $57 \mathrm{t}$. Ez a tömegérték a korábbi eszközökhöz képest igen nagynak számít, ami a műtárgyak - például hidak - terhelhetősége miatt befolyásolhatja a mobilitást is. $\mathrm{E}$ probléma azonban gondos múveleti tervezéssel és jól szervezett logisztikai támogatással kiküszöbölhető. Utóbbira jó példa a trélerek alkalmazása, ami napjainkban alapmegoldásnak számít és járulékos előnyökkel - például a személyzet pihentetésével, alacsonyabb tüzelőanyag-felhasználással, nagyobb menetsebességgel - is jár. A három üzemanyagtartályban elhelyezett gázolaj mennyisége mintegy 420 km-es távolság megtételére elegendő. A PZH 2000 motortérét automata tűzoltó rendszerrel is ellátták.

A tömegpusztító fegyverek elleni védelem más funkciót is ellát: a küzdőtér szellőztetését, ami egy ilyen harcjármű esetében kiemelt jelentőségű. A harceszköz személyzete maximum öt katona, a közvetlen kiszolgáláshoz azonban, bizonyos feltételek megléte esetében három fő is elegendő.

A harceszköz képességeit leginkább maga a $155 \mathrm{~mm}$ űrméretű, 52 kaliber ${ }^{3}$ hosszúságú, csőszáifékkel ellátott löveg biztosítja. A galvanizált, krómozott cső $8 \mathrm{~m}$ hosszú. Ez a kialakítás jelentősen növeli a kopásállóságot, ami nemcsak a hosszabb élettartamot, hanem a pontosságot is biztosítja. A cső élettartama 2000 lövés. A cső kialakításának minőségével nagyobb találati valószínűség érhető el, ezért egy-egy tűzfeladat végrehajtásához kevesebb lőszerre van szükség. A cső bajonettzáras rögzítésű, ami gyorsítja az esetleges csőcserét. A torony $360^{\circ}$-ban képes körbefordulni, a löveg $-2,5^{\circ}$ és $+65^{\circ}$-os szögtartományban képes működni. A toronyforgató és a célzó berendezések elektromechanikus kivitelüek. Ezt a technológiát biztonságosabbnak tartják, a tűzveszélyes hidraulika-folyadék hiánya miatt, mint a hidraulikus megoldást. A löveg tűzgyorsasága percenként 9-10 lövés. A töltőautomatához 30 db lőszert tartalmazó lánc is kapcsolható, ebben az esetben háromperces össztűzre képes.

A PzH 2000 az összes szabványos 155 mm-es NATOlövedék használatára képes. Az általános HE lövedék maximális lőtávolsága $30 \mathrm{~km}$, az ballisztikai süveggel ellátott lövedék esetén ez 40 km. A löveg automatikus töltőmechanizmussal rendelkezik. A tár befogadóképessége 60 lövedék. A rendelkezésre álló lőszertípusok köre sokrétű, a különféle repeszrombolókon, illetve ködfejlesztőkön kívül akár távaknásításra szolgáló is beszerezhető. A különleges hatzónás hajítótöltet egyszerübbé és biztonságosabbá teszi a kiszolgálást és csökkenti a különböző szerkezeti elemek terhelését, ami növeli az élettartamot, ezáltal hoszszabb távon csökkenti a költségeket. 


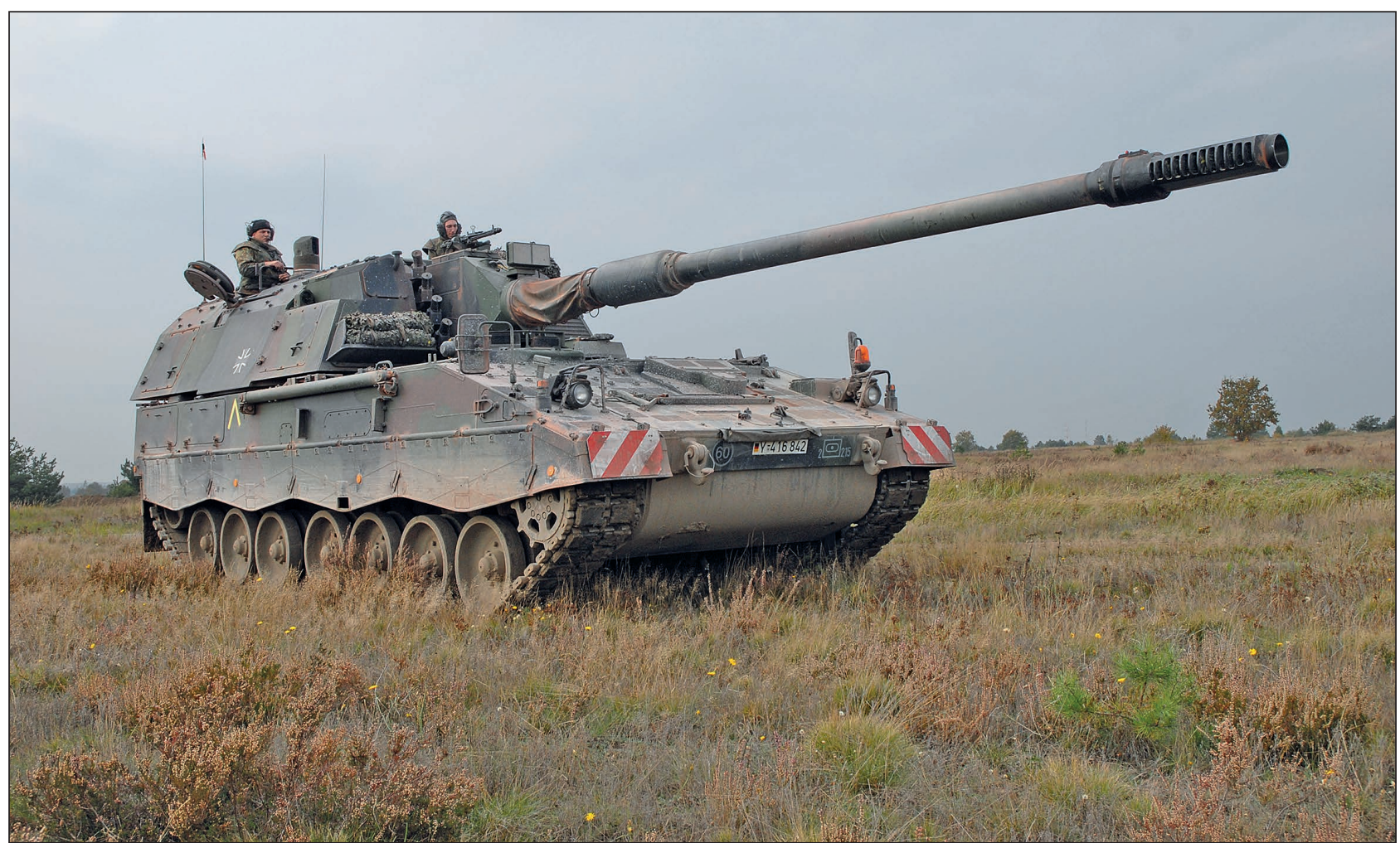

4. ábra. A Bundeswehr egyik PzH 2000-ese menetben, impozáns látvány a jármű fő fegyvere, a 155 mm ürméretű, 52 kaliber hosszúságú, csőszájfékkel ellátott lövegcső (Fotó: KMW)

Az automatikus töltőberendezés teszteredményei: három lövés $9,2 \mathrm{~s}$ alatt (normatív eredmény: $10 \mathrm{~s}$ ), nyolc lövés 51,4 s (60 s), valamint 20 lövés 2 perc 30 másodperc alatt (3 perc). Az eszközzel végzett próbák igazolták, hogy az automatizált célzási és töltési folyamatok, valamint a gyújtók beállítását szabályozó szoftverek segítségével a kétfős legénység (parancsnok és irányzó) kiváló eredményeket ért el. A személyzethez tartozik még két fő töltő is, akik a berendezés meghibásodása esetén manuálisan elvégzik a múveletet. A töltőrendszert a MOOG által gyártott kefe nélküli elektromos szervomotorok működtetik. A két töltő 12 percen belül 60 lőszert képes betölteni, beleértve a lőszeradatok programozásának időtartamát is.

A harceszköz, illetve a komplett rendszer igen kimagasló képességekkel rendelkezik. A magas szintű automatizáltságnak köszönhetően alkalmas például a Multiple Round Simultaneous Impact (MRSI) 4 üzemmódra is. Ez azt jelenti, hogy az adott fegyver ugyanarra a célpontra több eltérő röppályán keresztül is tüzelhet, tehát egyetlen lövegből az adott céltárgyra gyakorlatilag egyidőben akár 5 gránát is becsapódhat. A PzH 2000 esetében egyetlen tarack maximum $5 \mathrm{db}$ gránátot tud egy helyre eljuttatni, amihez ballisztikai okokból - a röppályán töltött minimális és maximális időtartam miatt - legalább 12 km lőtávolság kell. Az első és az ötödik becsapódás között alig több mint egy másodperc telik el, ami harchelyzetben elhanyagolható különbség, az ellenségnek megfelelő szintű reakcióra - különösen ellencsapásra - gyakorlatilag nincs lehetősége.

Az MRSI alkalmazása - a sikeres harctéri támadás érdekében - még a több löveggel rendelkező harctéri alegység számára is igényként jelentkezhet, a jövő hadviselése azonban éppen az egyre kisebb kötelékek irányába mutat.

Egy modern tüzérségi eszköz számos korszerű berendezéssel rendelkezik. A PzH 2000 esetében ilyen például a
Honeywell által gyártott navigációs rendszer, amely a tájoláson kívül a tengerszint feletti magasság meghatározására is képes. A rendszer müholdas vevőt is tartalmaz, de jelek hiánya esetén, autonóm módon is működőképes. A tűzvezetés az EADS cég számítógépének köszönhetően nemcsak manuálisan, hanem automatikusan is történhet. A harcjármű digitalizált tűzvezető rendszerébe csak a célpont UTM-koordinátáját kell beprogramozni, minden paramétert a modern rendszer számít ki a rendelkezésre álló adatok és az időjárás viszonyok alapján. Az ilyen automata üzemmód felügyeletéhez mindössze két katona szükséges, de az egész folyamat hagyományos módon, manuálisan is működtethető. Az automatikus működési módot rá-

5. ábra. A PzH 2000-es kiváló mozgékonysággal rendelkezik, ezért a hadszíntéren képes együtthaladni például a képen is látható Leopard 2-es harckocsikkal (Fotó: KMW)

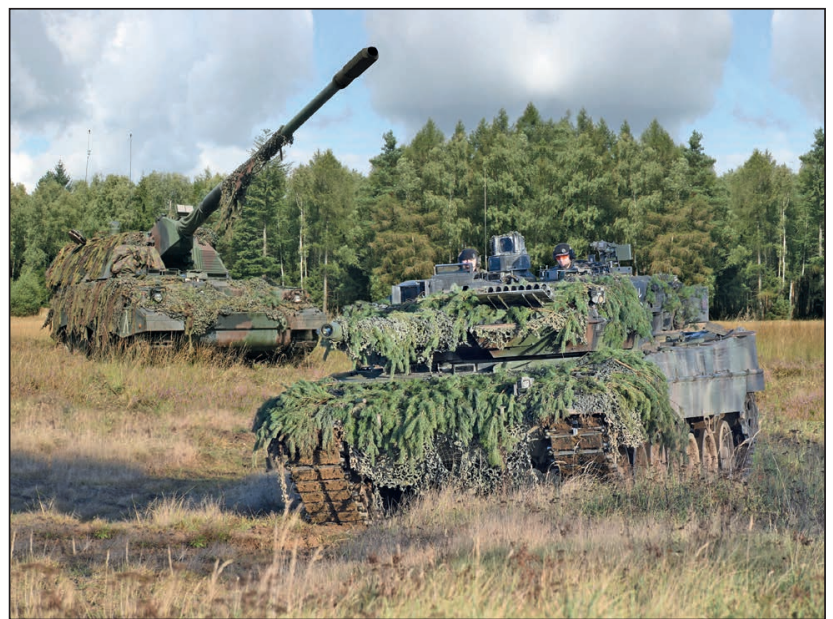




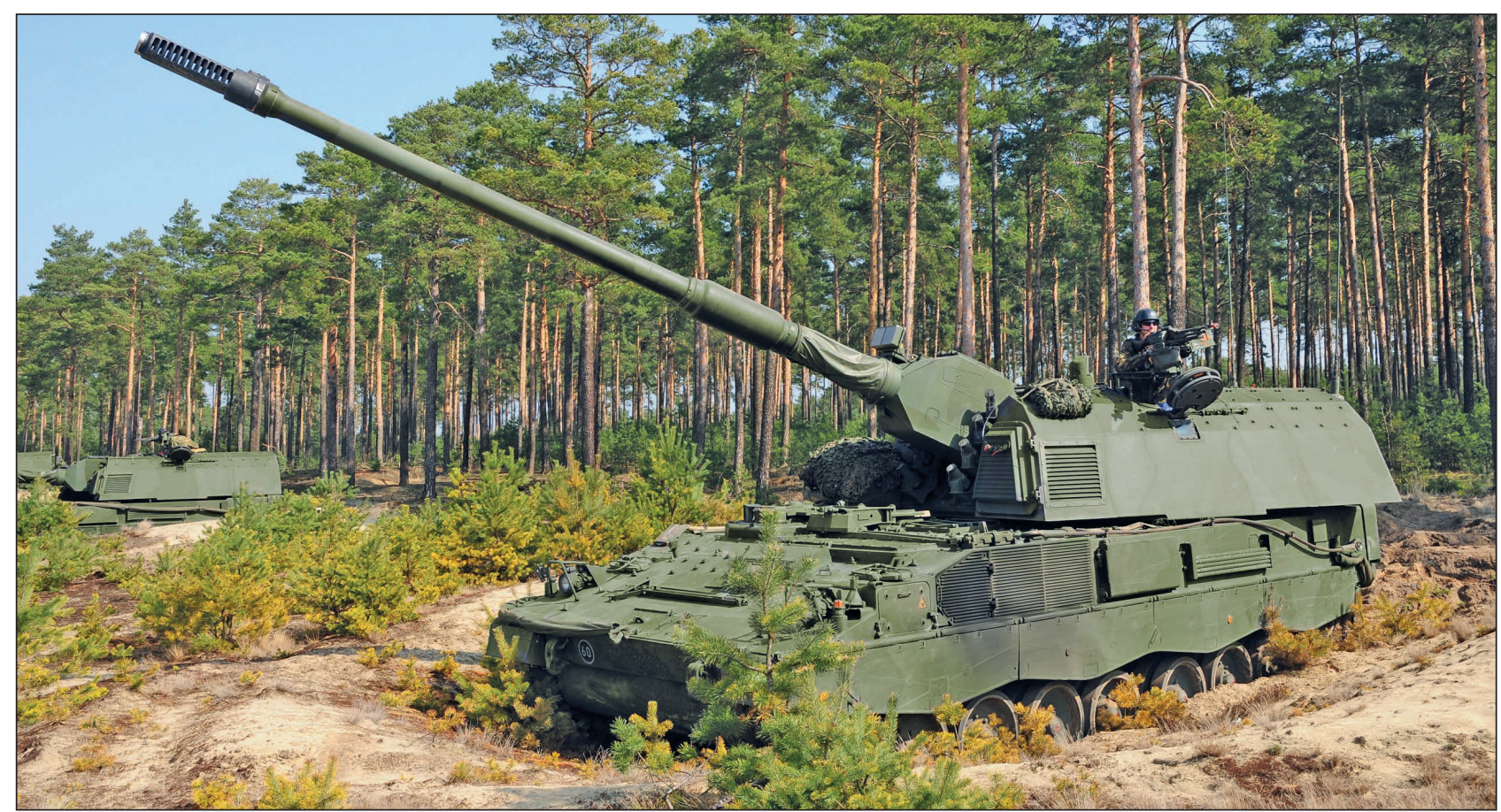

6. ábra. A legtöbb PzH 2000-es a NATO-szabvány szerinti vagy ahhoz hasonló, háromtónusú kamuflázst visel, de létezik kivétel: a horvát haderö önjáró lövegei például egységesen matt zöld festést kaptak

dió-adatkapcsolaton keresztül, egy külső C2 (Command and Controll - vezetés és irányítás) rendszer biztosítja az önjáró löveg számára. Az autonóm tűzvezetési funkciókat egy fedélzeti MICMOS számítógép végzi, amelyet az EADS (korábban a DaimlerChrysler Aerospace) szállított. Mindez nemcsak kényelmi célokat szolgál, hanem harcászati szempontból is kedvező, hiszen lerövidül a telepítés és a tűzkiváltás ideje, illetve megnő a találati valószínűség, ami a rendelkezésre álló információk szerint 40 km-es távolság esetén 30-40 m. A modern rendszereknek, illetve a nagyfokú automatizáltságnak köszönhetően a tűzmegnyitásra történő felkészülés ideje jelentősen lecsökkenthető, a menetből történő megállástól számítva két percen belül már végre lehet hajtani a tűzcsapást. Egyrészt az adott feladatrendszer kevesebb eszközzel is végrehajtható, másrészt a tüzelőállásban töltött rövidebb időnek köszönhetően az ellenséges felderítés, illetve ellentevékenység hatékonysága lecsökken. A parancsnok egy Leica PERI-RTNL 80 nagylátószögű periszkópon keresztül figyelheti a környezetet, és megjelölheti a célpontokat. A PERI-RTNL 80 nappali és éjszakai üzemmódban egyaránt működik és lézeres távolságmérővel is ellátták. A közvetlen irányzásra szolgáló Leica PzF TN 80 nappali és éjszakai használatra is alkalmas.

Az ellenséggel közvetlen harcérintkezésben lévő katonák biztonságának növelése mellett ez a „képességcsomag” költségcsökkentő tényező is, hiszen így egy-egy tűzfeladat végrehajtásához kevesebb lőszerre lehet szükség. Bár a mai modern gránátok költsége jóval magasabb, mint a régi technológiát tartalmazó pusztító eszközöké, a teljes költség összességében jóval kedvezőbb lehet. ${ }^{5}$ Ráadásul a nagyobb találati valószínűség a járulékos veszteségek szempontjából is komoly előrelépést jelent, ami napjainkban már minden művelettípus esetében kiemelt jelentőséggel bír.

Az alegység tűzvezető rendszeréből rendkívül gyorsan beérkeznek az adatátviteli berendezések által feldolgozott információk. Az ellenséges célpontok elleni közvetlen tűz- kiváltás szintén nagy hatékonysággal történhet. Az optikai eszközöket a nagy hagyományokkal rendelkező Leica cég gyártja, a pontos távolságmérést a lézeres távolságmérő segíti. Napjaink követelményeinek megfelelően az éjszakai képességekre is nagy hangsúlyt fektettek, a vezető is rendelkezik a harcjármú vezetéséhez szükséges passzív éjjellátó berendezéssel. A torony tetejére egy MG3 típusú $7,62 \mathrm{~mm}$-es géppuska is került. A személyzet biztonsága érdekében a $2 \times 4 \mathrm{db}, 76 \mathrm{~mm}$ űrméretű gránátvetővel ködfüggöny létesíthető, ami jelentősen hozzájárul a harcjármú túlélőképességéhez.

A modern harceszközökkel szemben sokszor vetik fel hátrányként, hogy korszerű technikai megoldásaik miatt a gyakorlatban történő alkalmazásuk a kezelők részéről fejlett szaktudást igényel. Ennek hiányában - valamint a valóban újdonságnak számító és formabontó technikai berendezések alkalmazása miatt - az eszközök használata során az átalgosnál gyakrabban történnek meghibásodások. Ez a megállapítás természetesen viszonylagos, de van némi igazságtartalma. Mindezt a PzH 2000 tervezői is felismerték, ezért a meghibásodások száma és súlyosságuk mértékének csökkentése, illetve a harcképtelenség idejének lerövidítése érdekében számos speciális technikai kialakítást is bevezettek. Ilyen például, hogy korlátozni próbálták a hidraulikus berendezések mennyiségét, többségük helyett egyszerűbb elektromos eszközöket építettek be, azokat is decentralizáltan, ami megkönnyíti a hibák elhárítását. Ehhez a hibafeltárásra is nagy hangsúlyt fektettek: a modern számítógépes diagnosztikának köszönhetően mindez gyorsabban és hatékonyabban történhet. Számos esetben a meghibásodott berendezés ellenére a harceszköz más üzemmódokban (például automata helyett, manuális üzemmódban) vagy tartalék rendszerek segítségével továbbra is harcképes maradhat. A javítás és karbantartás megkönnyítése érdekében modul rendszereket alkalmaznak, például a motort és a nyomatékváltót komplett egységben lehet ki- és visszaszerelni, ami nemcsak logisztikai, hanem harcászati szempontból is kedvező. 


\section{Hadrendben - Éles bevetés Afganisztánban}

Az első prototípusok 1993-ban készültek el, és a négy példánnyal több tízezer lövést váltottak ki, és közel százezer kilométert teljesítettek. Kiemelt szerepet játszott a szélsőséges éghajlati körülmények közötti tesztelés. Kanadában $-30{ }^{\circ} \mathrm{C}$ alatt hőmérsékletben teljesítettek több mint 3000 km-t, az USA Utah államának sivatagaiban pedig, több mint $+50^{\circ} \mathrm{C}$-os melegben $4000 \mathrm{~km}$-t.

A német haderő a képességek, illetve az akkori feladatrendszer alapján eredetileg 1254 db-ot rendelt, azonban a Szovjetunió, illetve a Varsói Szerződés felbomlását követően a megrendelt mennyiséget 185 db-ra csökkentették. A Bundeswehr számára történő sorozatgyártás 1998-ban kezdődött és 1992-ig tartott. A típussal az amerikai eredetű M109A3G-ket váltották le. Az új önjáró tarack kiválóan bevált, a Panzerhaubitze az ugyanolyan űrméretű és nem sokkal korábban modernizált elődhöz képest háromszor hatékonyabbnak bizonyult. Egy-egy tüzérosztály 3 üteggel rendelkezik, mindegyik állományába $8 \mathrm{db}$ harcjármű tartozik. Érdekességként említhető, hogy a típust eredetileg valamilyen állatról - Nashorn (rinocérosz), Stier (bika) - kívánták nevezni, végül erről lemondtak. A német haderő méretének folyamatos csökkentése a tüzérséget se kerülte el, napjainkban $101 \mathrm{db}$ PzH 2000 van használatban, a fennmaradók többségét eladták. Az éles példányokon túl a Bundeswehr néhány torony nélküli, vezetők oktatására szolgáló példánnyal is rendelkezik, amelyet mű lövegcsővel szereltek fel.

A típus iránt jelentős nemzetközi érdeklődés mutatkozott. A holland haderő 2002-ben 57 db eszköz beszerezését tervezte, végül $39 \mathrm{db}$ megrendelése mellett döntött. A rendszerbe állított példányok az M109 önjáró lövegeket és a vontatott tűzeszközöket váltották fel. Jelenleg $18 \mathrm{db}$ PzH 2000 aktív, további hatot kiképzésre használnak, a többi pedig tartós tárolásba került.

A típust a holland haderő Afganisztánban 2006-ban vetette be, ez volt a PzH 2000 történek első éles bevetése. Alövegeket az US Air Force C-17 típusú szállítórepülőgépein juttatták ki a hadszíntérre. A PzH 2000-esek több esetben is kiválóan teljesítettek, $30 \mathrm{~km}$-es lőtávolság esetén is hatékonynak bizonyultak. Több, számukra tragikus kimenetellel végződő tűzharcot követően 2010-ben a németek is bevetették Afganisztánban. A harcjárműveket májusban An-124 típusú repülőgéppel szállították Mazar-e Sharifba. A három löveg Kunduzba került volna, ám az egyik - eredetileg tartaléknak szánt példányt - harcászati szükségszerűség miatt végül az előretolt bázisra telepítették. Az igényeket kielégítve, még a nyár folyamán további két $\mathrm{PzH}$ 2000-est is Afganisztánba szállítottak. A típust nemcsak tűzcsapásra, hanem ködfüggöny létrehozására, sőt éjszakai harc esetén célpontok megvilágítására is felhasználták. A PzH 2000-esekkel kapcsolatos német és holland tapasztalatok megegyeztek egymással: az európai viszonyokra tervezett szellőztető rendszernek gondot okozott a magas hőmérséklet, illetve a poros környezet. Az afganisztáni hadszíntérre jellemző módon a felkelők sok esetben használnak aknavetőket, illetve különböző páncéltörő rakétákat az önjáró löveg ellen. A sajátos időjárási viszonyokból és a tálibok harctechnikájából adódó védelmi hiányosságokat plusz tetőpáncélzat felszerelésével enyhítették, amely nemcsak a ballisztikai védelmet javította, hanem a tűző nap ellen is nagyobb védelemet nyújtott. Ezt a megoldást légkondicionáló rendszerrel is kiegészítették, ami a személyi állományon kívül a lőszerek (hajítótöltetek) szempontjából is fontos volt. A lövegek az éles bevetések során kiválóan teljesítettek, jól kiegészítették az aknavetők, illetve a

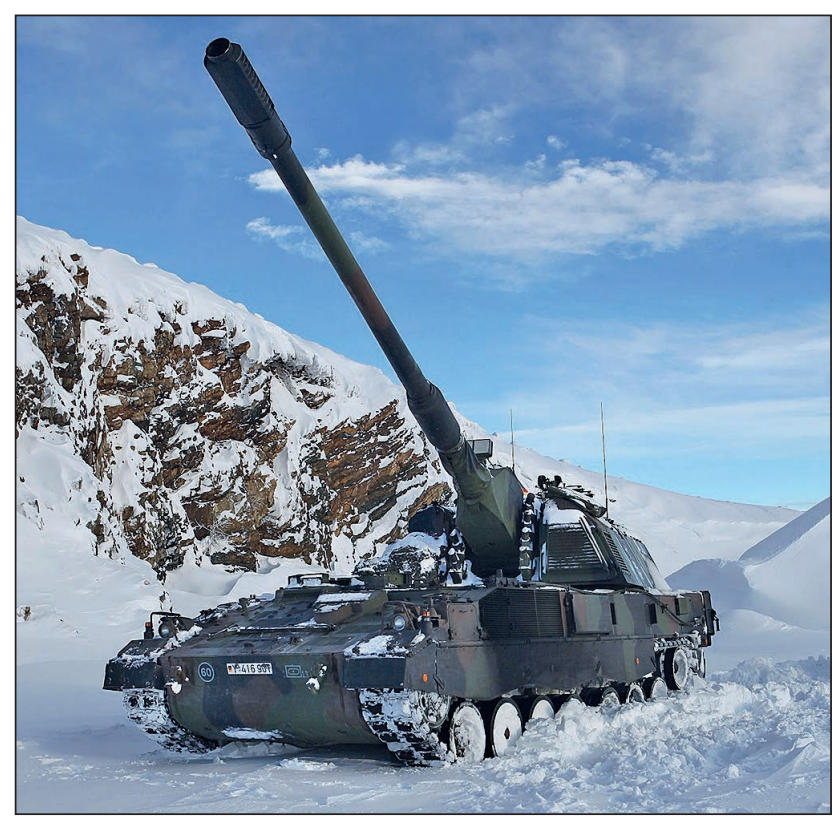

7. ábra. A PzH 2000-es magas színvonalú digitális lőelemképző rendszere biztosítja, hogy már az első tűzcsapás megsemmisítő erejü legyen (Fotó: KMW)

légi támogatási képességek lehetőségeit. ${ }^{6}$ A harcászati tapasztalatokon túl számos technikai, illetve logisztikai tapasztalatra is sikerült szert tenni, ezek nemcsak a típus, hanem a komplex tűztámogatási rendszerre nézve jelentősnek tekinthetők. A német PzH 2000-eseket 2013-ban vonták ki Afganisztánból.

A közép-ázsiai harcok során talán jól jött volna az a fejlesztés, amely hasonló hadszíntereken, aszimmetrikus hadviselés esetén a bázisok védelmére irányult. A rendszer „Szemét” képező radar felderíti a kilőtt rakétákat, amelyet a lövegek teljesen automatikus módon, repeszromboló gránátok közeli felrobbantásával megsemmisítenek. Egy közepes méretü objektumot ilyen rendszerrel három-négy $\mathrm{PzH}$ 2000-essel teljes mértékben meg lehetett volna védeni, ám a projekt végül abbamaradt.

Az M109L-ek leváltásának érdekében 2002-ben az olaszok is a PzH 2000 beszerzése mellett döntöttek. A 70 db-ból 2 db-ot a németek készítettek el, a többit pedig 2008-ig az Iveco és OTO Melara vegyes vállalata gyártotta le. Az eredeti két eszköz már kivonásra került, a hazai gyártásúak viszont továbbra is hadrendben vannak. Görögország 2001-ben 24 db PzH 2000GR-t (más források szerint a pontos típusjelzés $\mathrm{PzH} 2000 \mathrm{HEL}$ ) rendelt. A választásban a KMW céggel való korábbi együttműködés kedvező tapasztalati döntő szerepet játszottak. (Leopard 1-es harckocsibeszerzés, illetve amerikai eredetű eszközökhöz készített német kiképzési eszközök.) Ezek a példányok az eredeti német verzióhoz képest többek között a vezető plusz éjjellátó berendezésében, a kiegészítő légkondicionálóban, a továbbfejlesztett lézeres távolságmérőben, illetve a módosított kommunikációs rendszerben térnek el. Az eszközök leszállítása 2004-ben kezdődött. Katar 2013-ban egy Leopard 2A7-eseket is tartalmazó megállapodás keretében szintén 24 db önjáró tarack beszerzéséről döntött. A szállítás két évvel később kezdődött, az új eszközök ebben az esetben a régebbi francia technikát váltották le. Érdekes, hogy a kiképzési csomag egy részét nem a németektől, hanem a görögöktől vásárolták meg.

A horvátok 2014-ben egy 55 millió eurós szerződés keretében 16 példány beszerzéséről döntöttek. A harcjármű- 


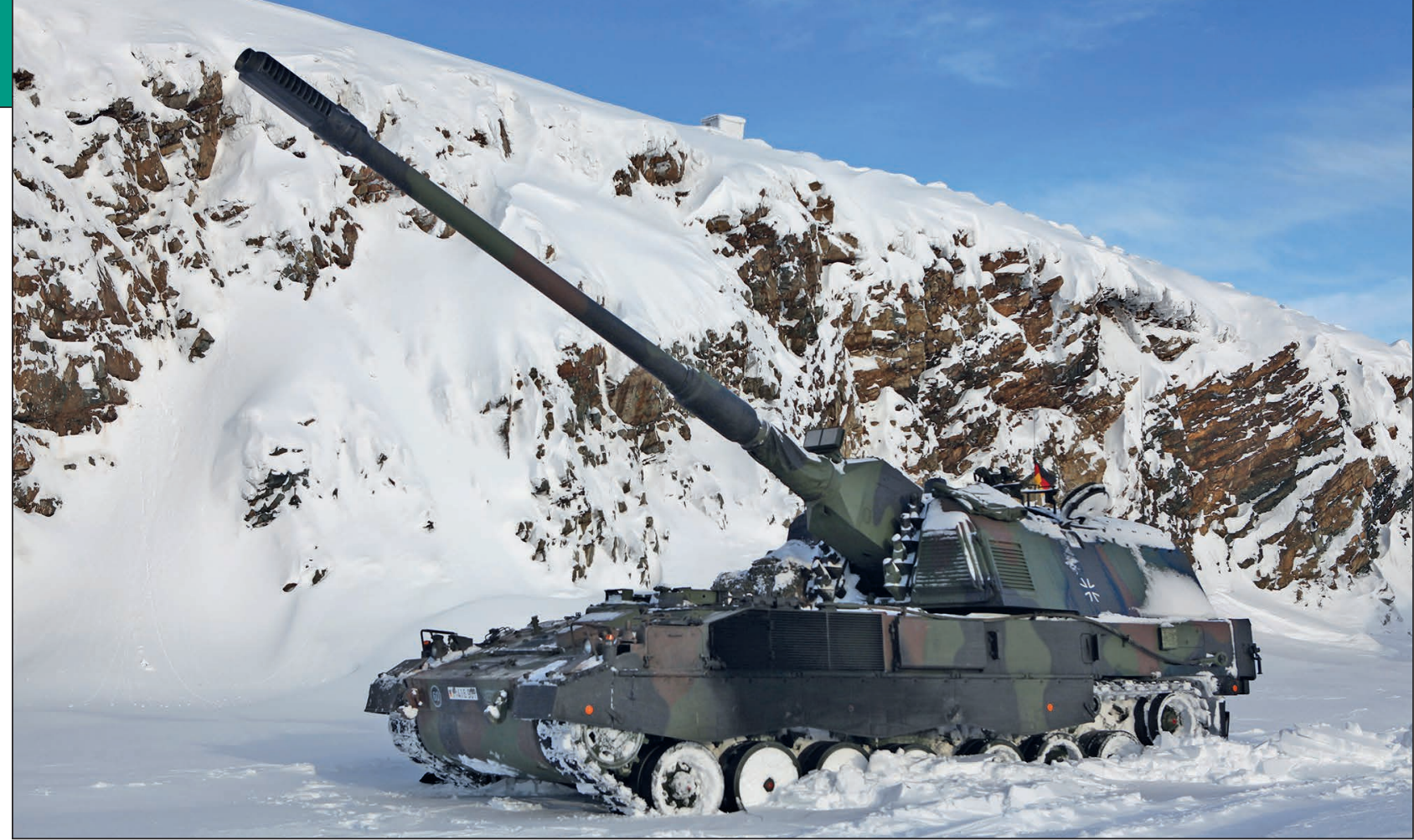

8. ábra. Szembetűnő a PzH 2000-es tekintélyt parancsoló mérete. Az önjáró löveg elegendő belső teret biztosít a személyzet és hadfelszerelés elhelyezésére. Az eszköz nehéztréleren közúton, levegöben pedig C-17-es és An-124-es repülőgépeken is szállítható (Fotó: KMW)

vek a Bundeswehr készleteiből származtak. A lövegek egy részét modernizálták, amit csak az „éles” eszközökön végeztek el, az egyetlen kiképzésre szolgáló lövegen, illetve a három donor járművön azonban nem. A harcjárművek közül néhányat viszonylag hamar leszállítottak, majd a nyilvánosságnak történő bemutatás érdekében részt vettek egy díszszemlén, és csak ezt követően végezték el rajtuk a modernizációt. A hadrendbe állítás 2019 során történt meg. Litvánia 2015-ben egy 58 millió eurós üzletet kötött a németekkel. A különféle harci eszközöket tartalmazó megrendelésben 21 db használt, korszerűsített PzH 2000 önjáró löveg is szerepelt. Az első két példányt 2018 decemberében szállították le, a többire pedig a következő évben, 2019-ben került sor.

A Bundeswehr által értékesített $\mathrm{PzH}$ 2000-esek naprakész működtetésést folyamatos karbantartással biztosítják a különböző NATO-államok. A folyamat során gyakran berendezéseket cserélnek le vagy építenek be, ám előfordul, amikor szoftveres frissítésekkel érnek el jobb eredményt, például a számítógép által vezérelt kommunikációs rendszer korszerűsítésével.

A fegyver beszerzési és fenntartási költségei igen magasak, az általa biztosított képességeknek köszönhetően öszszességében azonban már kedvező lehet a megvásárlása. A Varsói Szerződés korábbi tagállamainak egy része tüzérségi tapasztalatokkal is felvértezett, komoly fegyvergyártással is rendelkezik, ennek ellenére a PzH 2000 esélyes lehet a jövőbeli tendereken. Ráadásul a kategóriájában csúcsminőséget képviselő eszközt a jelenleg hadrendben álló saját lövegek mellett is érdemes lehet rendszeresíteni, például a NATO reagáló erőbe felajánlott, kiemelt jelentőséggel bíró gépesített egységek esetében. Az is fontos tényezőnek bizonyulhat, hogy maguk a kelet-európai tagállamok is egyre több Leopard családba tartozó harcjárművel rendelkeznek, amire kevésbé közismert példa a románok Gepard önjáró légvédelmi gépágyújának beszerzése.

A sikerek mellett azt is meg kell említeni, hogy a típus beszerzése több országban is elmaradt. Ilyen volt például Svédország, amely a 2000-es évek elején tesztelte az eszközt. Bár a harcjármű kialakításának köszönhetően a bonyolult terepen jól teljesített, a nagy tömeg azonban gon- dot okozott, többek között a hidak korlátozott teherbírása miatt. A beszerzés elmaradásának másik oka a magas költség volt. A finnek szintén tesztelték, ám a költségeket végül ők is magasnak találták.

\section{Magyar felséGJellel}

Ahogy láthattuk a PzH 2000 napjaink egyik legkorszerübb önjáró lövege. A Magyar Honvédség egyik problémája jelenleg a korlátozott tűztámogatási képesség, ami egyrészt a korábbi évtizedek mennyiségi leépítése, másrészt az elmaradó minőségi fejlesztések miatt következett be. Ezen belül talán a tábori tüzérség jelenti az egyik legnagyobb problémát. A Zrínyi 2026 haderőfejlesztési program keretében hazánk 24 db PzH 2000-est szerez be a KMW cégtől. A típus a korábban használt, önjáró kialakítású, páncélozott 2Sz1 Gvozgyikához, illetve a 2Sz3 Akácijához, de még a hadrendben lévő D-20-ashoz képest is generációs ugrást jelent. ${ }^{8}$ Mindez természetesen magára a lövegcsőre is igaz, hiszen a teljesítményt - például lőtávolságot tekintve - is megfelel a XXI. század követelményeinek. A platform szintén kiváló, magas szintű védelmet és mobilitást biztosít, ami létfontosságú a tűztámogatáshoz. Más jellegű, ám fontos tényező, hogy a harceszköz teljes mértékben NATO-kompatibilis, ezáltal nincs szükség utólagos módosításokra, például a kommunikációs berendezések esetében (ez egyébként a finanszírozáson túl logisztikai és garanciális szempontból is nagy előny). A legnagyobb előrelépést az automatizált működés, illetve az elektronikai eszközök által nyújtott, XXI. századi technológiát biztosító képességcsomag jelenti, például a hatékony tűzvezetés vagy éppen az MRSI.

Az üzemeltetési feltételek szintén nagyon fontosak, gyakorlatilag ezek határozzák meg a harceszköz köré épített rendszer képességeit. Az alkalmazott lőszerek már NATOszabvány szerint készültek és a korábbiakhoz képest minőségi előrelépést is jelentenek. A logisztikai, kiképzési és más jellegű támogatások nemcsak katonai, hanem finanszírozási szempontból is hatékonyak. Példaként említhető a modern szimulátorok alkalmazása, amelyekkel nemcsak 
1. táblázat. A PzH 2000 fontosabb technikai adatai

\begin{tabular}{|c|c|c|}
\hline \multicolumn{2}{|c|}{ Kezelőszemélyzet } & \multirow{2}{*}{$\begin{array}{c}\text { max. } 5 \text { fő } \\
\text { (parancsnok, } \\
\text { vezető, irányzó, } \\
2 \text { fő töltőkezelő) } \\
11,67 \text { m } \\
\end{array}$} \\
\hline \multirow{2}{*}{ Hosszúság } & teljes, löveggel & \\
\hline & páncéltest & $7,30 \mathrm{~m}$ \\
\hline \multirow{2}{*}{ Szélesség } & teljes & $3,58 \mathrm{~m}$ \\
\hline & kötény nélkül & $3,37 \mathrm{~m}$ \\
\hline \multirow{2}{*}{ Magasság } & teljes & $3,46 \mathrm{~m}$ \\
\hline & torony nélkül & $3,06 \mathrm{~m}$ \\
\hline \multicolumn{2}{|c|}{ Hasmagasság } & $0,44 \mathrm{~m}$ \\
\hline \multirow{2}{*}{ Lánctalp } & szélessége & $550 \mathrm{~mm}$ \\
\hline & felfekvése & $4,91 \mathrm{~m}$ \\
\hline \multirow{2}{*}{ Tömeg } & üres tömeg & $49 t$ \\
\hline & harci tömeg & $55,33 \mathrm{t}$ \\
\hline \multirow{2}{*}{ Erőforrás } & & MTU 881 dízelmotor \\
\hline & teljesítmény & 735 kW (1000 LE) \\
\hline \multicolumn{2}{|c|}{ Nyomatékváltó } & $\begin{array}{c}\text { Renk HSWL } 284 \text {, } \\
\text { automata, } 4 \text { elöre-, } \\
2 \text { hátrameneti fokozat }\end{array}$ \\
\hline \multicolumn{2}{|c|}{ Felfüggesztés } & torziós \\
\hline \multicolumn{2}{|c|}{ Fajlagos teljesítmény } & 13 kW/t (18 LE/t) \\
\hline \multicolumn{2}{|c|}{ Sebesség (max.) } & $60 \mathrm{~km} / \mathrm{h}$ \\
\hline \multicolumn{2}{|c|}{ Hatótávolság } & $420 \mathrm{~km}$ \\
\hline \multicolumn{2}{|c|}{$\begin{array}{l}\text { Emelkedő-kapaszkodó } \\
\text { képesség }\end{array}$} & $50 \%$ \\
\hline \multicolumn{2}{|l|}{ Oldaldőlés } & $25 \%$ \\
\hline \multicolumn{2}{|c|}{ Lépcsőmászó képesség } & $1 \mathrm{~m}$ \\
\hline \multicolumn{2}{|c|}{ Árokáthidaló képesség } & $3 \mathrm{~m}$ \\
\hline \multirow{3}{*}{ Fegyverzet } & fő & $\begin{array}{c}155 \text { mm-es } \\
\text { L/52-es ágyútarack }\end{array}$ \\
\hline & másodlagos & $\begin{array}{l}\text { 7,62 mm-es MG3 } \\
\text { típusú géppuska }\end{array}$ \\
\hline & ködgránátvetők & $\begin{array}{c}2 \times 4 \mathrm{db}, \\
76 \text { mm-es gránátvető }\end{array}$ \\
\hline
\end{tabular}

* Forrás: IHS Jane's Land warfare Platforms: Artillery \& Air Defense 2016-2017

pénz és technika, hanem idő is megtakarítható. Az eszköz alkalmazása környezetvédelmi szempontból is rendkívül pozitív. Sőt, a mai oktatási eszközökkel olyan környezeti, stb. feltételek is megteremthetők amelyeket éleslövészeten biztonsági okokból tilos végrehajtani. ${ }^{9} A$ tervezés során kidolgozott elveket ismét célszerű kiemelni, hiszen az üzemeltetést várhatóan nagymértékben megkönnyíti majd a haderőfejlesztési program során szintén a KMW cégtől megvásárlásra kerülő Leopard harcjárműcsalád. Ugyanakkor a típus beszerzése - a többi modern harceszközhöz hasonlóan - komoly kihívások elé állítja a Magyar Honvédséget, hiszen a program logisztikai, infrastrukturális, humán, kiképzési és minden egyéb szempontból soha nem tapasztalt igényekkel jelentkezik. Ráadásul a követelmények nemcsak mennyiségi, hanem egyre nagyobb mértékben minőségi szempontból is kiemelkedőek, elég csak a személyi állománytól elvárt magas szintű képzettségére, például nyelvtudására, vagy az informatikai ismeretekre gondolni. A nehézségek ellenére a modern eszközök hadrendbe állítása létfontosságú. A haderőfejlesztési program a Magyar Honvédég számára lehetővé teszi a tűztámogatási képesség technikai NATO-szintű felzárkóztatását.

\section{FELHASZNÁLT IRODALOM}

„Vehicles in focus: Panzerhaubitze 2000” Letöltve: 2019.09.16. https://aw.my.com/us/news/general/ vehicles-focus-panzerhaubitze-2000;

Bundeswehr. „Die Panzerhaubitze 2000” Letöltve: 2019.09.16. https://www.bundeswehrentdecken.de/ aktuelle-reportagen/panzerhaubitze-2000;

„M109A3G” Letöltve: 2019.09.16.

http://www.army-guide.com/eng/product1777.html;

MTU Online. „Engines for heavy vehicles” Letöltve:

2019.09.16. https://www.mtu-online.com/mtu/products/ engine-program/diesel-engines-for-wheeled-andtracked-armored-vehicles/engines-for-heavy-vehicles/;

Foss, Christofer F., O'Halloran, James C. IHS Jane's Land Warfare Platforms: Artillery and Air Defence 2016-2017: Krauss-Maffei Wegmann Panzerhaubitze 2000. Couldson. IHS, 2016.

\section{JegYzetEK}

1 STANAG: angolul Standardization Agreement, NATO egységesítési egyezmény.

2 A szárazföldi csapatok esetében hatalmas előnyt jelent, ha az adott egység harceszközei hasonló tulajdonságokkal rendelkeznek. Nemcsak a lövész harcjármüvek és a harckocsik esetében, hanem a tüzérségnél is, hiszen az adott tájegység terepviszonyai az utakról letérni kényszerülő lövegekre ugyanúgy hatnak, mint a többi említett eszközre. 3 A kaliberhosszúság az aktív csőhosszúság és a névleges ürméret hányadosa, ami ebben az esetben $155 \times 52=8060 \mathrm{~mm}$.

4 A szerző az Multiple Round Simultaneous Impact (MRSI) kifejezésre tüzér szakemberek segítségével se talált magyar megfelelőt. Talán „egyidejüleg több lövedékkel végzett csapásnak” lehetne nevezni.

5 Ez a repülöbombákat modernizáló precíziós fegyverek bevezetéséhez hasonló tendencia volt. Bár az új eszközök az eredeti árának többszörösét tették ki, egy-egy célpont megsemmisítéséhez vagy lefogásához a régi fegyverekből akár több tucatnyi is kellett, míg a korszerübből akár egy is elég lehet, így a teljes költség lecsökkenhet.

6 A harctéren tapasztalt hatékonyságot mi sem jellemzi jobban, minthogy a két oldalon harcolók az „ISAF hosszú karja”, illetve a „Tarin Kowt fenevadja" nevet emlegették.

7 Ez egyébként nemcsak a PzH 2000-re igaz, hanem nemzettől függetlenül gyakorlatilag minden modern harceszközre. Jó példa lehet erre a magyar JAS-39 Gripen, amelynek szoftveres frissitése már több esetben is nyilvánosságra került.

$8 \mathrm{~A}$ beszerzés ellenérveként sokan felvetik, hogy a 2Sz1, illetve a 2Sz3 modernizált változatai is igen hatékonynak számítanak. Ahhoz azonban, hogy ezek a 30-40 éves harcjárművek megfeleljenek napjaink követelményeinek, a kommunikációs rendszert, az erőforrást, az irányzó eszközöket, sőt magát a löveget is ki kellene cserélni bennük. Modern navigációs és adatátviteli rendszerre van szükség. Az ilyen jellegủ munkák elvégzését követően egyes paraméterek - például a védettség - továbbra is az 1970-es évek színvonalán maradnának. (Ez a felvetés az említett harceszközöknek a Magyar Honvédség hadrendjéből több évtizeddel ezelőtti kivonása miatt már aktualitását vesztette.)

9 A modern szimulátorokkal olyan körülmények is imitálhatók, amelyek esetében az éles lövészet nem lenne biztonságos. llyen lehet például a szélsőséges időjárási körülmény (például nagy szél, köd), a lakott település közelsége vagy éppen megfelelő lőtér hiányában a nagy távolság. 